\title{
Artikel
}

\section{Pilots in de jeugdbescherming, een motor voor reflectie, vragen en innovatie}

\author{
Mr. W. Helmich*
}

Het stelsel van jeugdbescherming krijgt veel aandacht. In dit artikel wordt specifiek stilgestaan bij innovatie, de totstandkoming hiervan en hoe deze innovatie leidt tot overwegingen voor een volgende stap richting de toekomst van jeugd- en gezinsbescherming.

\section{Achtergrond}

Op 30 januari 2018 werd door de ministers van Justitie en Veiligheid en van VWS de evaluatie van de Jeugdwet aan de Tweede Kamer (TK) aangeboden. Hiermee werd voldaan aan artikel 12.2 van de Jeugdwet om binnen drie jaar na inwerkingtreding van deze wet verslag uit te brengen over de doeltreffendheid en de effecten van de wet in de praktijk. Een relatief snelle evaluatie, waar in 2013 al bij amendement om werd verzocht (de oorspronkelijke evaluatietermijn werd daarmee vervroegd van vijf naar drie jaar). In het voorjaar van 2016 werd de Tweede Kamer verzocht de evaluatie aan te merken als een tussenevaluatie. ${ }^{1}$

De tussenvaluatie is gebaseerd op vier deelstudies en maakt inzichtelijk hoe de Jeugdwet tot en met de zomer van 2017 uitpakt voor kinderen en ouders en voor gemeenten als regisseurs van het jeugdbeleid en voor jeugdhulpaanbieders en -professionals. Bij het afronden van het onderzoek werd zichtbaar dat de ontwikkeling en de implementatie van beleid nog in volle gang waren.

* Mr. W. Helmich is eigenaar van Helmich Interim en Advies. Zij heeft een brede achtergrond binnen de Jeugdbescherming. Onlangs droeg zij het projectleiderschap voor de pilots Jeugdbescherming over om aan de slag te gaan als kwartiermaker voor het te ontwikkelen toekomstscenario voor Jeugd- en gezinsbescherming in Nederland.

1. Kamerbrief Evaluatie Jeugdwet 30 januari 2018.
Daarmee werd de evaluatie (opnieuw) als een tussenstand gekenmerkt.

De hoofdconclusie van de betrokken onderzoekers is dat de veranderingen sinds de invoering van Jeugdwet vooral te kenmerken zijn als een transitie en dat de gewenste transformatie, gericht op de realisatie van de doelen van de wet (tijdig passende hulp, meer samenhang), grotendeels nog vorm moet krijgen. ${ }^{2}$ Ook constateren de onderzoekers dat ondanks bovengenoemd feit de gewenste transformatie en de transformatiedoelen van de Jeugdwet breed worden gedragen, door zowel gemeenten als aanbieders. Eind maart 2018 rapporteert de Transitie Autoriteit Jeugd (TAJ) dat de overgang van betere en veilige zorg voor kwetsbare jongeren in een zo vroeg mogelijk stadium, nog in de kinderschoenen staat. $^{3}$

In reactie op de uitkomsten van de tussenevaluatie ontstaat er een nieuwe impuls in de samenwerking tussen Rijk, gemeenten en anbieders, om de jeugdhulp, de jeugdbescherming en de jeugdreclassering te verbeteren. Hierbij is de oriëntatie en samenwerking regionaal en de ondersteuning landelijk. Dat vertaalt zich in het programma Zorg voor de Jeugd dat als hoofddoel heeft om de jeugdhulp, de jeugdbescherming en de jeugdreclassering merkbaar en meetbaar steeds beter te maken voor kinderen, jongeren en gezinnen, zodat ze op tijd passende hulp ontvangen.

Dat hoofddoel wordt vertaald naar zes actielijnen. Deze kennen ieder voor zich een brede uitwerking:

1. betere toegang tot jeugdhulp voor kinderen en gezinnen;

2. meer kinderen zo thuis mogelijk laten opgroeien;

2. Eerste Evaluatie Jeugdwet, ZonMW januari 2018, hdst. 8 samenvatting, conclusies en aanbevelingen (par. 8.2).

3. Rapportage TAJ, 28 maart 2018. 
3. alle kinderen de kans bieden zich optimaal te ontwikkelen;

4. kwetsbare jongeren beter op weg helpen zelfstandig te worden;

5. jeugdigen beter beschermen als hun ontwikkeling gevaar loopt;

6. investeren in vakmanschap van jeugdprofessionals.

Actielijn 5 richt zich op het eerder en beter beschermen van kinderen die worden bedreigd in hun ontwikkeling. De uitwerking van deze actielijn bevat een aantal onderdelen die daaraan kunnen bijdragen. In dit artikel sta ik specifiek stil bij onderdeel 1 van actielijn 5, namelijk: 'We korten de Jeugdbeschermingsketen in. Betere samenwerking, minder overlap en gedeelde afwegingscriteria verhogen de snelheid in de keten.' Dit onderdeel heeft geresulteerd in het opzetten (regionaal) en ondersteunen (landelijk) van zes Jeugdbeschermingspilots.

\section{Operationaliseren}

Het doel van de pilots is om te ontdekken waar zich de grootste mogelijkheden tot verbetering binnen de huidige jeugdbeschermingsketen bevinden en hoe verbetering er in de praktijk uit kan zien. Daarmee dragen de pilots ook bij aan het inzichtelijk maken waar wet- en regelgeving mogelijk knelt.

De deelnemende gemeenten werd gevraagd om met

bovengenoemde doelen een nieuwe samenwerking tussen (in ieder geval) wijkteams, Gecertificeerde Instellingen, Raad voor de Kinderbescherming en Veilig Thuis vorm te geven en de opgedane kennis landelijk te delen. Deze nieuwe samenwerkingsverbanden, de pilots, werden uitgedaagd om vernieuwend te denken en met het belang van de cliënt voorop waar nodig de randen van vigerende wet- en regelgeving op te zoeken en hierbij zo veel mogelijk los te komen van de bestaande organisatiegrenzen en -structuren. Ter ondersteuning is door de VNG en de ministeries van J\&V en van VWS een landelijke structuur ingericht. Deze voorziet in het in positie brengen van een landelijk projectleider om zo de kennis die is opgedaan in de pilots te verbinden tussen de pilots en aan de ministeries en toezichthouders en vice versa. Tevens is een juridische vraagbaak ingericht voor de beantwoording en agendering van juridische vraagstukken. Verder zijn er financiële middelen beschikbaar gesteld om de projectstructuur lokaal te faciliteren.

In de vroege zomer van 2019 zijn zes pilots Jeugdbescherming gestart: in Rotterdam-Rijnmond, Amsterdam Amstelland, West Brabant West, Zeeland, het Gelders deel van Food Valley en Utrecht. Gezamenlijk starten met en uitdenken van een nieuwe werkwijze zag er op alle plekken anders uit. De ene pilotlocatie was al aan de gang met een nieuwe werkwijze, de andere pilot is gestart met onderzoek hoe een nieuwe werkwijze vorm te geven. Er waren verschillen in schaalgrootte, reikwijdte, het al dan niet eerst lopen van een bestuurlijk besluitvormingsproces alvorens de werkwijze te operationaliseren en de mate van beschikbaarheid van professionals. Voor meer inhoudelijke informatie verwijs ik naar de interviews over werkwijze, aanpak en ervaringen op het platform van Zorg voor de Jeugd. ${ }^{4}$ Leren binnen, tussen en over de pilots zijn als belangrijkste elementen aangemerkt om profijt te kunnen hebben en te leren voor de toekomst. Om dit leren te stimuleren en op alle niveaus in gang te zetten, is in januari 2020 het Athena Instituut van de Vrije Universiteit Amsterdam ${ }^{5}$ gestart om deze zes unieke pilots via de weg van action learning te volgen en te evalueren. Bijna gelijktijdig met de publicatie van dit artikel worden de resultaten van het onderzoek, uitgevoerd door het Athena instituut, bekendgemaakt.

Evaluatie van de pilots vraagt om een manier van werken die passend is bij de werkwijze in de pilots, hun context en de gecombineerde behoefte aan verantwoorden enerzijds en leren anderzijds. De betrokkenheid van het Athena Instituut en de evaluatie hebben daarmee de volgende doelen:

1. het bevorderen van reflectie op drie niveaus: leren binnen de pilots (reflectie op de gekozen methode(n), de wijze van samenwerken, zowel operationeel als bestuurlijk en de verbetering van werkprocessen), leren tussen de pilots (delen van lessen over en weer) en leren van de pilots (inzicht in wet- en regelgeving, financieringsstructuren en andere generieke systeemcondities die de verbeteringen belemmeren of bevorderen). Daarbij wordt rekening gehouden met de lokale verschillen per pilotlocatie;

2. toetsing op de vooraf opgestelde doelen of successen die de pilots zouden moeten opleveren;

3 . het formuleren van de essentiële gezamenlijke waarden binnen de jeugdbescherming, werkzame bestanddelen in relatie tot output en impact van de pilots: dat wil zeggen de waarden/mechanismen die hebben bijgedragen an het beter beschermen van jeugdigen die gevaar lopen in hun ontwikkeling. Het gaat hier om de essentiële werkzame bestanddelen van de aanpak (het proces) en de vormen waarin betrokken organisaties gezamenlijk integraal werken, met aandacht voor integratie van infrastructuur, organisatie, financiering en besluitvorming;

4. inzicht in mogelijkheden voor, en bijdrage aan, opschaling van de verbeterde praktijken in de jeugdbescherming en jeugdhulp buiten de pilots en richting de evaluatie van de Jeugdwet en de Kinderbeschermingswetgeving.

\section{Hoe nu verder}

Inmiddels zijn de zes pilots ruim een jaar verder en tekenen de eerste resultaten zich af. Resultaten voor gezinnen, professionals, rode draden van structuren die 
schuren en waar wetgeving helpt of de aanpak in de weg staat. Zoals hiervoor al beschreven zijn de deelnemende partijen op de zes plekken nagenoeg dezelfde en wordt in alle gevallen gezamenlijk zo effectief mogelijk gewerkt aan zorgen over veiligheid in gezinnen. De vorm, de mate van verandervermogen en de intensiteit waarmee dit in pilotverband plaatsvindt, verschilt.

We hebben (wederom) geleerd dat als organisaties en mensen - van bestuurders, gezinnen tot professionals en van opdrachtgevers tot stelselverantwoordelijken elkaar, elkaars (wettelijke) bevoegdheden, verantwoordingsmechanismen en werkwijze echt goed kennen, er vertrouwen ontstaat. Vertrouwen en begrip helpen enorm om met elkaar een (nieuwe) samenwerking vorm te geven en opnieuw na te denken over samenwerken. Ook geeft het in veel gevallen de impuls om niet vanuit organisaties maar vanuit gezinnen te redeneren bij het nadenken over wat deze gezinnen verder helpt. Alvorens in te gaan op de vervolgstappen, sta ik kort stil bij drie in mijn ogen belangrijke inzichten voor de toekomst.

\section{Experimenteren; een ingewikkeld aantrekkelijke uitnodiging}

Buiten vertrouwen en elkaar begrijpen is het van belang om met elkaar hetzelfde doel voor ogen te hebben en heel precies te onderzoeken voor wie waarom onderdelen van dat doel in meer of mindere mate belangrijk zijn. Wat wil ieder van de partijen bereiken en niet verliezen? Ook in hoeverre je samen 'echt' anders kan samenwerken als nog niet alle signalen op groen staan, waardoor de trekkracht van moederorganisaties, bestaande wet- en regelgeving maar ook toezichtmechanismen blijven bestaan. Experimenteren is een prachtige uitnodiging en tegelijkertijd ontzettend ingewikkeld omdat het, als het goed gebeurt, ingaat tegen de gevestigde ordening en deze ordening niet in haar geheel mee-experimenteert. Experimenteren brengt ook grote en daarmee soms ongemakkelijke vraagstukken aan de oppervlakte waarvan de gevolgen soms moeilijk te overzien zijn. Te denken valt aan de grondslag van gemaakte keuzes in de Jeugdwet, de knip tussen regie en hulpverlenen en ook of een kinderbeschermingsmaatregel wel een passende maatregel is als de problematiek oudergerelateerd is.

\section{Eén samenhangend geheel}

Steeds meer zie ik de parallel tussen de positie van de gezinnen en die van professionals. In het woud van absoluut goed bedoelde en met reden ontworpen regels, verantwoordingsmechanismen, protocollen en verschillende bevoegdheden krijg ik steeds meer de indruk dat gezinnen en professionals niet meer kunnen overzien wat er van hen verwacht wordt en hoe dat in verbinding staat met het grotere geheel. Dat vraagt in mijn ogen een heroriëntatie op een zorgvuldige en tegelijkertijd meer simpele en transparante inrichting van het werk, de benodigde functionaliteiten en bevoegdheden. Daarnaast zie ik het belang van optimaal en constant ondersteunen van professionals, opdat zij maximaal kunnen leren en reflecteren en bij gezinnen kunnen blijven (en) aansluiten.

\section{Het gezin}

Het paradigma wijzigt: waar er aan het begin van deze pilotperiode een duidelijk onderscheid gemaakt werd tussen het kind en het gezin (de ouders), wordt er nu gesproken over het gezin of het systeem. Met dat paradigma ligt de weg naar de toekomst open en ontstaan er mogelijkheden om het begeleiden en ondersteunen van gezinnen waar zorgen zijn op andere wijze vorm te geven. Dat vraagt een andere manier van kijken en oplossingen toepassen die buiten het jeugddomein liggen. Dat betekent mogelijk ook het in de praktijk anders toepassen van bevoegdheden en wetgeving door met een integrale blik naar oplossingen binnen het hele gezinssysteem te kijken.

Daarmee ligt er ook op juridisch vlak nog een ander lonkend perspectief: hoe zou het toepassen van het bestuursrecht, het civiele recht en het strafrecht uitpakken als de zorgen over de veiligheid binnen gezinnen of het feit dat je een gezin hebt en daarmee verantwoordelijkheden draagt, steeds een onderdeel van afwegingen zouden zijn. Bijvoorbeeld: hoe kan een pakket aan (juridische) maatregelen zo afgestemd worden dat het bijdraagt aan het herstellen van veiligheid in een gezin? Denk bijvoorbeeld aan de invulling van bijzondere voorwaarden in het strafrecht, de mogelijkheid van het inzetten van een tijdelijk huisverbod of bewindvoering. Zomaar een aantal juridische instrumenten naast de ondertoezichtstelling en de uithuisplaatsing die van nut kunnen zijn om de zorgen over veiligheid in een gezin weg te nemen en perspectief op de toekomst te bieden. Dit vraagt van eenieder die beroepsmatig bij een gezin is betrokken een holistische wijze van redeneren en werken.

De tussenevaluatie van de Jeugdwet, de jeugdbeschermingspilots en de vele andere prachtige initiatieven in het land, maar ook een onderzoek als dat van het Athena Instituut en het nog op te leveren onderzoek door het Verweij-Jonker Instituut waar met gezinnen onderzocht wordt of de huidige aanpak van kindermishandeling en huiselijk geweld werkt, ${ }^{6}$ zijn belangrijke bronnen die bijdragen om te komen tot een ontwerp voor de toekomst. Het Signalement Feugdbeschermingsketen in gevaar ${ }^{7}$ van de IGJ en IJ\&V heeft de urgentie voor een heroriëntatie benadrukt. De ministers Dekker en De Jonge hebben de 
Tweede Kamer in maart 2020 toegezegd $^{8}$ om an het einde van dit jaar te komen met een nieuw scenario voor jeugd- en gezinsbescherming. Dat scenario kent in ieder geval de volgende uitgangspunten: een gezinsgerichte aanpak volgens een eenduidige gezamenlijk visie, van estafette naar teammodel, transparant, toegankelijk en makkelijk uit te leggen aan gezinnen.

Samen met de betrokken partijen (van toezicht tot ervaringsdeskundige, van uitvoering tot wetenschap en van bestuurder tot burger) wordt de komende maanden gewerkt aan een nieuw scenario waarin de opgedane kennis een plek krijgt en het denken vanuit samenwerken met gezinnen en hun netwerk het paradigma is.

\section{Ter afsluiting}

Dit moment is een prachtkans om opnieuw te kijken naar wat we niet willen verliezen en wat we anders willen. Maar welke inrichting van een stelsel ook gekozen wordt, het zal vragen om wijzigingen op alle niveaus, zodat de gezinnen en de kinderen die zich in het stelsel van (gedwongen) zorg bevinden ook echt op andere wijze begeleid en ondersteund kunnen worden. De kunst is een inrichting te ontwerpen die ook de kracht van het gezin - en de naasten die bij dat gezin en de kinderen horen - stimuleert om gezamenlijk te werken aan het herstellen van veiligheid of het compenseren van onveiligheid. Dat gaat verder dan jeugdbescherming, wijkteams of volwassenzorg, maar betreft het geheel aan private en publieke verbindingen dat een gezin heeft. Dat is complex, maar is dat niet precies wat er in het leven gebeurt? Iedere verandering op school, een werkplek of een verhuizing heeft invloed op de dynamiek binnen een gezin. Dat maakt dat veel mensen hierop invloed kunnen hebben. Misschien een (te) positieve en spannende zienswijze, want wat als het misgaat? Wie was er dan verantwoordelijk voor de veiligheid? We zijn geneigd hierop steeds te willen anticiperen en risico's te willen uitsluiten, maar keer op keer blijkt weer dat situaties onvoorspelbaar en niet maakbaar zijn. En dat al die regels en protocollen ook een keerzijde hebben. En, zijn we uiteindelijk niet allemaal verantwoordelijk? Met elkaar, als buren, als familie, als lokale en als centrale overheid, als ouders en als juf. Niet alleen als het misgaat of moeilijk is, maar altijd in een mensenleven. Soms is in dat mensenleven extra (gedwongen) hulp, zorg of compensatie nodig. Dat moeten we dan met elkaar goed, transparant en toetsbaar organiseren.

En, misschien nog wel het belangrijkste, daarover moeten we dan longitudinaal blijven leren, zodat we de komende jaren gaandeweg (lokaal, regionaal en landelijk) kunnen volgen hoe de aanpak en samenwerking in en met gezinnen vorm krijgt. Zodat bijsturen, ten behoeve van gezinnen en de professionals die met de gezinnen werken, tijdig en constant kan plaatsvinden. 